\title{
At forbinde steder - turistoplevelser på farten
}

\author{
JøRGEN OLE BARENHOLDT*
}

Title: Linking places - tourist experiences while on the move.

Abstract: There are many facets to the ways in which we experience places. Each individual links places with other people, and these linkages can be material, bodily, social, recollected, imagined and fantasy-based in nature. This article examines a range of recent contributions to understanding the concept of place within the context of mobility. This is done primarily on the basis of the most recent research relating to both geography and tourism - research that features ideas from a range of different performance-oriented approaches.

These are approaches that on the one hand bring an important focus on the material, bodily and social aspects of experiencing a sense of place via phenomenology, and that on the other hand must involve additional dimensions above and beyond the immediately apparent, and incorporate aspects of imagination and fantasy. Three separate studies - relating to Allinge Harbour, the Hammershus fortress and The Viking Ship Museum - serve to show how the experience of place involves linkages and traces that transcend many different types of time and space.

Key words: Recollection, imagination, phenomenology, cultural heritage, materialism, mobility, experience, social behaviour, location, tourism.

\section{INDLEDNING}

Der er noget underligt med steder, de findes jo uden at være befolkede og forestillede, men alligevel ikke. I denne artikel vil jeg vise, hvordan steder dårligt kan forstås, uden at man ud over det fysiske og images også inddrager menneskers kropslige involvering, sociale relationer og erindringer. Når disse dimensioner indgår, ender vi op med et helt andet (be)greb om steder. Det er en forståelse, som gør det nemmere for os at forstå, hvordan turister 'ta- ger til', gennem og 'gør' steder - og derved gør dem til oplevelser undervejs. Det som virkelig udfordrer vor forståelse er dog, hvordan denne konkrete og ret så mobile omgang med steder virker sammen med fantasier - hvad min kollega Michael Haldrup og jeg har kaldt en 'fantastisk realistisk' bearbejdning af steder som spor af noget andet og mere (Bærenholdt og Haldrup 2004). Netop i denne dobbelthed af stedets konkrete dimensioner og så de ikke mindre virkelige men dog fantasifulde forestillinger omkring stedet ligger en mulighed for 
at forstå, hvorfor så mange bliver ved med at mobilisere turistoplevelser af steder. Men det er samtidig en dobbelthed som giver analysen og fortolkningen teoretisk udfordringer. Ikke alene må vi overskride images og det rent fysiske og tillægge en fænomenologisk tilgang til stedets kropslighed, socialitet og erindring. Vi er også uundgåeligt udleveret til fantasier og forestillinger, som i vor egen iscenesættelse og 'performance' bliver langt mere håndgribelige og realistiske, end vi måske ellers vil(le) være ved. For at forstå dette må vi kombinere indsigter fra forskellige teoretiske traditioner, som hver giver vigtige men hver især i sig selv utilstrækkelige bidrag til at analysere og forstå turisters performance af sted. Fire teoretiske traditioner vil her efterhånden blive bragt i spil: en mikrosociologisk, en diskurs- og magtorienteret, en fænomenologisk og hvad der kan kaldes en 'fantastisk orientering'. Der findes næppe en analyse af turisters performance af steder, hvor en af traditionerne kan stå alene, men det er samtidig oplagt, at de forskellige traditioner ikke har den samme relevans for forståelse af forskellige former for performance af steder. Derfor foretager jeg, efter en indledende teoretisk diskussion af hvordan vi 'gør' steder (do places), en slags gradvist begrebsudviklende rejse gennem tre turiststeder fra Allinge Havn, op over Hammershus slotsruin, for at ende på Vikingeskibsmuseet i Roskilde; en rejse som efterhånden nærmer sig oplevelsen af kulturarv. De tre steder er valgt fordi jeg gennem tidligere forskning, samt gennem min egen personlige tilknytning til disse steder (gennem regelmæssigt tilbagevendende turistbesøg eller bosætning), har fundet, at de i deres sammenstilling giver mulighed for at udfolde en interessant forskellighed $\mathrm{i}$ den måde, turister 'performer' dem. Det er en forskellighed, som har informeret den indle- dende teoretiske diskussion af forskellige tilgange til performance. Snarere end casestudier, er der således tale om begrebsudviklende etnografier. Artiklen udgør således en kritisk gentænkning af tidligere internationalt publiceret forskning fra disse steder.

\section{AT FA STEDER TIL AT LEVE OP - OVERVEJ- ELSER OM MOBILITET, OPLEVELSE OG PER- FORMANCE}

Steder forbindes med meget forskellige typer af processer, og det er netop samspillet mellem disse forskellige betydninger, som danner grobund for begrebets spændstighed. Som empirisk felt anvendes sted på én gang som en betegnelse, som knytter sig til bosted, turiststed, og kulturarvssted, samt mere strategiske stedsudviklingsprojekter. Det er ofte forskellige typer af teoretiske begrebsdannelser, som knytter sig til disse felter. Måske med god grund i mange tilfælde. Men det er også et problem, hvis afgrænsning og begreber isolerer vores forståelse af, hvordan steder virker i forbindelse med menneskelig praksis. At isolere vores analyse af sted til kun ét perspektiv betyder, at vi ikke for alvor forstår, hvad steder betyder. Det isolerede stedsperspektiv findes i forskningen både $\mathrm{i}$ de rent humanistiske tilgange orienteret mod individets perception og i de rent materialistiske tilgange, som reducerer sted til kun lokalitet. Denne artikel tager afsæt i en tilgang til at forstå sted, hvor der altid er en kompleks flerhed af steder, mennesker og perspektiver på spil. Derved bliver det muligt at undersøge, hvordan forskellige og overlappende stedsperspektiver virker sammen, både inden for samme lokalitet og på tværs af lokaliteter.

Tilgangen er forankret i den nyere kultur- og samfundsgeografiske tradition, som opfatter 
steder som praktiserede og relationelle. Steder anskues her i og med den sociale praksis, de indgår i. Steder er, ligesom rum, således mere end rent fysiske lokaliteter og også mere end rent individuelle oplevelser. To markante repræsentanter for denne grundtilgang er den britiske geograf Doreen Massey (1994, 1995 og 2005) og den danske geograf Kirsten Simonsen (1995, 2001, 2005 og 2008, og se Buciek et al. 2006b). Steder bliver her dynamiske og praktiserede og dermed $i k k e$ givne og $i k k e$ forankrede i et uforanderligt rum. Det er en opfattelse, der udfordrer traditionelle forståelser af sted som stabilt, bofast og hjemligt, og dermed rejser spørgsmål om, hvem der har ret til hvilke steder, deres kulturarv og fortællinger. Sociale relationer har rumlig udstrækning og steder bliver således til ('become') gennem både nære og fjerne forbindelser (Massey 1995). I en senere bog, giver Massey (2005) indspil til en fænomenologisk forståelse af sted som 'throwntogetherness'. Derved understreger hun, at steder ikke kun bliver til gennem politiske og økonomiske processer, men også indeholder en slags mere eksistentiel udleverethed mellem mennesker til at leve med hinanden på steder.

En mere udfoldet fænomenologisk inspireret tilgang til sted findes hos Kirsten Simonsen (2001, 2005 og 2008). Med inspiration fra Merleau Ponty anses menneskets krop som en før-diskursiv social realitet, som er grundforudsætningen for menneskers sansning, erfaring og oplevelse. Kroppen ' "kender" sig selv i kraft af sin aktive forholden sig til verden omkring sig' (Simonsen 2001: 37). Oplevelse og praktisering af selvet og af steder er derfor altid først og fremmest kropslig. Kroppen udgør her i sig selv det mindste sted, som både er et subjekt og et objekt. Men steder er samtidig også socialt praktiserede i mødet mellem for- skellige kroppe. Og i sine nyere arbejder, lægfølelser, narrativer og erindringer, som opstår i mødet mellem mennesker. Steder bliver således konstrueret gennem kombinationen af kropslig erfaring, følelser, narrativer og erindringer (Simonsen 2008), hvor især narrativer men også den sociale orientering lægger yderligere perspektiver til den rent fænomenologiske inspiration (se diskussioner om diskurser og repræsentationer i Buciek et al. 2006b). Særligt i sin tilgang til sted som kropslig praksis minder Simonsens arbejder om forståelsen af sted og landskab hos den britiske antropolog Tim Ingold (2000 og med Mazzullo, 2008). Flere af disse perspektiver er blevet bragt $\mathrm{i}$ anvendelse $\mathrm{i}$ analysen af, hvordan steder forbruges og opleves af turister, men det er karakteristisk at disse studier foruden den kropslige forståelse også lægger vægt på sociale relationer, erindringer og mere diskursive forestillinger (Urry 1995, Bærenholdt et al. 2004).

Når steder på den måde forstås i forbindelse med menneskelig praksis og sociale relationer, betyder det også, at stedet dårligt kan tænkes uden samtidig at se på mobile praksisser. Det gælder for det første i den rent fysisk-kropslige forstand, at steder ikke kan tænkes uden den bevægelse, som forbinder dem. '...there can be no places without paths, along which people arrive and depart; and no paths without places' (Ingold 2000: 204). Men denne komplementaritet mellem sted og mobilitet gælder bredere, ligesom sted er mere end lokalitet/lokalisering, er også mobilitet mere end bevægelse. Mobilitet forhold sig til fysisk bevægelse, som sted forhold sig til fysisk lokalisering (Cresswell 2006, Bærenholdt og Granås 2008). Både mobilitet og sted inkluderer også det sociale og kulturelle. At steder således er 
forbundet med og integrerer både materiel, social og kulturel praksis, herunder mobilitet, har endelig den implikation, at steder er både rumlige og tidslige.

Steder konstrueres og leves i både tid og rum. Ligesom de kan have bestemte afgrænsninger og udstrækning i rum, har de også udstrækning og afgrænsning i tid. Det ligger for så vidt allerede i udgangspunkt: Når steder praktiseres og ikke er taget for givet, stabile kategorier, betyder det, at de kan forgå. Det er derfor, det giver god mening at tale om performance af steder, for steder bliver til gennem de, ikke mindst mobile, performances som kontinuerligt skaber, nedbryder og genskaber dem som materielle, sociale og kulturelle steder (Bærenholdt et al. 2004).

Når oplevelser studeres med en praksistilgang til sted, indebærer det dermed et begreb om oplevelser, som egentlig rummer begge betydninger af det engelsk 'experience'. Det indeholder både erfaring (Erfahrung på tysk) som den dybt socio-materielle proces, hvorigennem mennesker tilegner sig omverden ved at bevæge sig og fare igennem, og så oplevelse (Erlebnis på tysk) i betydningen, at mennesker liver op gennem sanseindtryk (Löfgren 1999: 95). En vis form for grundforståelse af, hvordan mennesker oplever steder, er hermed allerede introduceret. Men det rejser samtidig en lidt nærmere diskussion af, hvordan steder opleves, forbindes og 'performes'. Her gælder det særligt om at undersøge, hvordan oplevelser indeholder en mere aktiv, handlende, 'performance' af de, som oplever.

\section{FORSKELLIGE TILGANGE TIL PERFORMANCE}

En ny performanceorienteret tilgang til turismeforskning har været diskuteret, men det forbliver et spørgsmål, hvordan performance nærmere skal forstås (se Edensor 2000, Coleman and Crang 2002, Bærenholdt, Haldrup og Larsen, I Trykken). Performancebegrebet anvendes her i den samfundsteoretiske betydning. Skønt brugen af dette engelske ord på dansk også kan konnotere til sceneoptræden, performance design, økonomisk eller management performance, bruges begrebet her teoretisk til at diskutere nogle nærmere karakteristika ved den menneskelige praksis, som er involveret i oplevelsen af steder. I forhold til megen turismeforsknings fokus på diskurser og repræsentationer, angiver performance begrebet i første række egentlig blot en orientering mod de konkrete praksisformer, som er involveret $\mathrm{i}$ at gøre, forbinde og opleve steder.

Performancetilgangen $\mathrm{i}$ turismeforskning bygger således klart på den praksistilgang til steder, som er skitseret ovenfor. Men i forhold til praksistilgangen, kan performance begrebet bidrage til nærmere at konkretisere forståelsen og analysen af de former for praksis, som indgår $\mathrm{i}$ at opleve. For at gøre dette, er det nødvendigt kort at referere til fire forskellige tilgangsvinkler til performancebegrebet. Et centralt spørgsmål, som adskiller tilgangene, er om steder som scener (som materialitet eller diskurs) selv former performance, eller om steder netop produceres gennem performance. Et andet spørgsmål er, hvordan stedsoplevelsen er forbundet til (forestillinger om) andre steder. De fire orienteringer er den mikrosociologiske, den diskurs- og magtorienterede, den fænomenologiske og hvad der kan kaldes den 'fantastiske'.

Ervin Goffman (1959) præsenterede den klassiske mikrosociologiske teori om performance. Han så hverdagslivets interaktion i en dramaturgisk ramme, hvor mennesker flytter sig mellem forskellige scener, som kræver og muliggør forskellige former for performance. 
Han skrev i den forbindelse om 'front-stages' og 'back'stages'. Selvet findes ikke forud, men kommer til sig selv igennem performance, sådan som den kan udfolde sig på bestemte scener. Der er tale om en slags social forhandling om roller og scener, hvor det for menneskelig praksis hele tiden er afgørende, at man handler i bevidstheden om, at der er et (evt. fremtidigt) publikum, som man må forholde sig til. Goffmans tilgang vægter i høj grad den sociale interaktion.

En anden tilgang udgøres af Judith Butlers arbejde med performativitet (1993). Hun er mere orienteret mod diskurser og magt (fra Foucault), som går forud for subjektet. Performance bliver derved udtryk for former for rutinepræget praksis, som er indskrevet med bestemte former for mening. Performativitet bliver derved en forståelse, der synes at lægge op til at performance er knyttet til et allerede eksisterende 'manuskript'. Ulempen ved denne tilgang er, at den tendentielt lægger op til et fraværende eller i det mindste passivt, ikke kreativt, subjekt. Men samtidig må det erkendes, at performativitet også bidrager til vores forståelse af, hvordan allerede eksisterende betydninger og forestillinger indgår i den måde mennesker oplever på. Det kan f. eks. være udbredte og tillærte forestillinger om betydningen af bestemte steder eller artefakter; betydninger som formidles gennem den i samfundet levende kulturhistorie. Få vil være i tvivl om at der er magtrelationer involveret $i$ oplevelser.

Hertil kommer en tredje og på flere måder lidt mindre præcis eller mere sammensat tilgang, som lægger vægt på performance som kropslig og materiel. Det er her vi finder fænomenologien hos bl.a. Tim Ingold - men også den såkaldte (og ikke specielt godt navngivne) 'Non-representational Theory' hos den britiske geograf Nigel Thrift, der også har diselsen, at den sociale verden bliver til igennem hverdaglige performances, som også involverer oplevelser af og kropslige involveringer med den materielle omverden. Det sociale, kropslige og materielle bliver derved svært at skelne fra hinanden. Der ligger også i denne tradition en kritik af den form for konstruktivisme, hvor kulturelle repræsentationer og diskurser bliver de afgørende iscenesættende faktorer. Der er således et tydeligt slægtskab mellem den 'ikke-repræsentationelle', eller bedre 'mere-end-repræsentationelle', tradition og den moderne nordiske kultur- og samfundsgeografi, som bl.a. Simonsen repræsenterer (Haldrup 2006: 104). Men der er forskelle inden for denne kategori mellem på den ene side den kropsligt og materielt orienterede fænomenologiske tilgang hos antropologen Ingold og på den anden side de 'mere-end-repræsentationelle' tilgange. Sidstnævnte leder særligt når den bliver 'mere-end', snarere end 'ikke', orienteret mod repræsentationer over mod den fantastiske orientering, som jeg (senere) afslutter med.

Tim Ingold er i sin fænomenologiske tilgang optaget af at overvinde modernitetens skel mellem ånd og natur, mellem mening og materialitet. Med inspiration fra den økologiske psykolog Gibson indfører han derfor et begreb om 'affordance' for at forstå, hvordan landskaber og steder så at sige muliggør bestemte oplevelser og erfaringer. 'A place owes its character to the experiences it affords to those who spend time there - to the sights, sounds and indeed smells that constitute its specific ambience' (Ingold 2000: 192). Kulturel mening bliver dermed helt klart forstået mindre konstruktivistisk. Man kan endda sige, at Ingold er lige ved at gå i den modsatte 


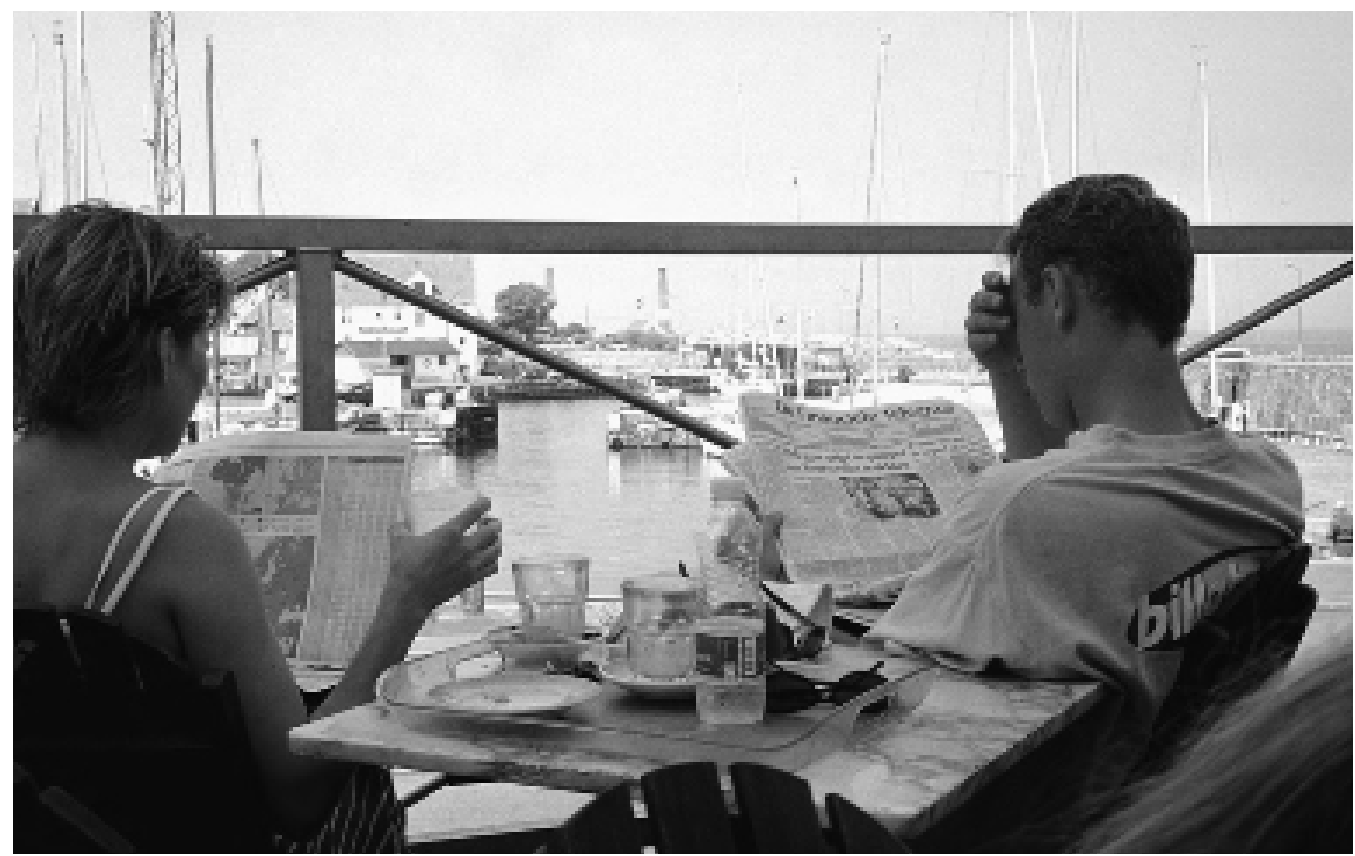

Udenlandske turister på cafe-besøg ved Allinge Havn. Foto: Jørgen Ole Barenholdt.

grøft, fordi han opfatter steders og landskabers mening som noget der samles fra steder og landskaber. Mening og betydning er noget andet end blot lag der kan skrælles af virkeligheden. Mening kan hos Ingold ikke løsrives fra de forskellige sansers natur, som han også diskuterer i mere fysiologiske termer. Meget er vundet ved denne tilgang, men den er pga. sin næsten konsekvente aflivning af forestillinger om magt og samfundsmæssige repræsentationer utilstrækkelig. Her bliver det næsten alene den enkelte krop på stedet, som sanser, og der tales faktisk heller ikke om performance. Tilgangen går $\mathrm{i}$ en vis forstand $\mathrm{i}$ den modsatte grøft af Butlers performativitet. Samtidig tilføjer Ingold henholdsvis Butler hver på deres side væsentlige aspekter i forhold til Goffmans oprindelige mikrosociologiske formulering:
Sansning af omgivelser henholdsvis diskurser og magt.

Andre tilgange, i familie med Thrifts arbejde, er inspireret af Aktør-Netværks Teori (ANT) og de rødder den (ligesom Butler) også har hos Michel Foucault. Den britiske samfundsog kulturteoretiker Kevin Hetherington er et fremtrædende eksempel på en sådan tilgang; han har bl.a. arbejdet med museumsverdenen (se f.eks. 1999). Her gælder det imidlertid hans ideer til forståelsen af steder: '... place is a contingent effect of the processes of placing, ordering and naming that emerge from the actions of heterogenous materials within a given network and the system of differences that are generated to give stability to such a mobile process' (Hetherington 1997: 192). I den ANT-inspirerede tilgang indgår materielle ar- 
tefakter i handlinger, på en ofte omdiskuteret måde, men fordelen ved denne tilgang er dens store åbenhed over for de forestillinger og fantasier, som mobiliseres. Terminologien er kendetegnet ved en karakteristisk kompleksitet, hvor der i stedet for at tage noget som helst for givent, sættes fokus på netop de processer i virkeligheden, som faktisk stabiliserer ellers flydende og mobile systemer og processer. Han siger f.eks. også: 'Places circulate through material placings, through the folding together of spaces and things and the relations of difference established by those folds' (Hetherington 1997: 187). Rummet kan ligesom tid foldes og orden og differentiering findes ikke forud - men det er netop hvordan de bliver til, som skal studeres. Steder bliver mobile ligesom skibe. Associationer, fantasier og artefakter forbindes på ikke altid forudsigelige måder.

Hermed er den fjerde, fantastiske, orientering allerede antydet. Jeg vil først udfolde den nærmere senere $\mathrm{i}$ forbindelse med tolkningen af turistperformance på Vikingeskibsmuseet. Men den fantastiske orientering rummer ligesom Hetherington en klassisk inspiration fra kritiske teori og her særligt Walter Benjamin. Dertil en inspiration fra litteraturteorien hos den store fortæller Tolkien! 'Fantastisk realisme' vil blive brugt til at forstå hvordan turister gennem fantasier idet de kropslige sanser kan opleve og iscenesætte/opføre ('performe') langtrækkende forbindelser i tid og rum til andre og ikke mindre virkelige verdener.

Skønt de forskellige teoretiske inspirationer, som jeg nu har præsenteret, rummer en række problemer og indbyrdes forskelle, giver de alle interessante inspirationer til at gøre nærmere konkrete studier af, hvordan steder opleves og forbindes af turister på farten. Det vil fremgå, at nogle tilgange synes mere oplagte til at for- stå bestemte former for performance af sted, mens andre tilgange passer bedre til at forstå andre former.

\section{OM MATERIALITET, KROP, SOCIALITET, ERIN- DRING OG BILLEDER PÅ ALLINGE HAVN}

Allinge Havn på Bornholm er et eksempel på en turismelokalitet, som er rammen om ganske almindelige turistoplevelser, der måske netop fordi de er ret så almindelige, alt for ofte overses i forskningen. Allinge Havn er på sin vis blot et lille købstadsmiljø, hvor både lokale og turister foretager hverdagsaktiviteter og heriblandt først og fremmest forskellige former for indkøb. Men det foregår også en del slentreture, der ofte kombinerer elementer såsom indblik i livet ombord på lystbådene i havnen, betragtning af ankommende, afsejlende og passerede skibe, besøg i talrige souvenir- og gavebutikker, besøg på røgeri og i kiosker for indkøb af og fortæring af fiskeprodukter og is, almindelig slentresamvær, cafebesøg (se foto 1) og evt. deltagelse i musikarrangementer (jazzfestival en uge hver sommer) eller lignende. Konteksten er her en almindelig sommerdag i rimeligt godt vejr, hvor der som regel vil være mellem 100 og 500 som bevæger sig rundt i havneområdet. Forfatterens feltarbejde i form af deltagerobservation og interview med turister foregik på nogle dage i somrene 2001 og 2002 (se Bærenholdt et al. 2004: kapitel 3).

En stor del af aktiviteterne på og omkring Allinge Havn næres af den fortætning af forskellige former for mobilitet, som finder sted her. Det er jo for det første en havn, hvor fortidens udskibning af granit og fiskeri nu er erstattet af et stort opbud af store lystbåde; hvoraf mange bruger Allinge som første eller sidste havn i tilknytning til deres kalkulerede sejlads over åbent hav til den svenske kyst. Turistbåde 
12 til Christiansø og Simrishamm er også på spil. Dernæst gennemskæres Allinge Havn af den nordbornholmske 'hovedvej' til Sandvig, Hammeren og Hammershus. Selvom der er en mindre vej gennem Slotslyngen, og trafikken i Allinge er delt i to traceer (se figur 1), passerer den mest brugte vejforbindelse mod sydøst gennem Havnegade på kanten af havnen. Som en del af et EU-støttet projekt blev Havnegade ensrettet og renoveret med brolægning i 2002; en udvikling som kun har forstærket cafe- og slentre miljøet omkring havnen. Endelig er Allinges to supermarkeder (de to som har overlevet) lokaliseret ganske nær på havnen og med P-plads i tilknytning til havnen og havet, og mange både lokale indbyggere og turister kombinerer derfor 'naturligt' indkøb med 'en tur på havnen'. Al denne aktivitet er måske især bemærkelsesværdig, fordi Allinge Havn ikke er genstand for nogen særlig opmærksomhed i turistbrochurer eller guidebøger. Alligevel viste feltarbejdet, at der her er mange forskellige stedsoplevelser på spil. Disse oplevelser, for ikke at sige stedet som sådan, bliver til igennem gæsternes performance. Allinge Havn er således et meget anderledes sted at besøge udenfor turistsæsonen; turister i lystbåde, på sejlads og på slentretur gør således en stor forskel i forhold til en anden hverdag, som kun er præget af de lokales indkøb. Et turismested kan altså blive til gennem netop turisternes egen aktivitet.

Studiet af turismeperformance på Allinge Havn gav anledning til at foreslå et femdimensionalt stedsbegreb (Bærenholdt et al. 2004: kapitel 3). Der er, for det første, tale om sted som fysisk miljø. Allinge Havn er i sin indretning kendetegnet ved en særlig rumlig fortætning, skabt af bygningerne, kajanlæg med moler og bølgebrydere til sammen med havnebassinet, som i forbindelse med tysk ejet

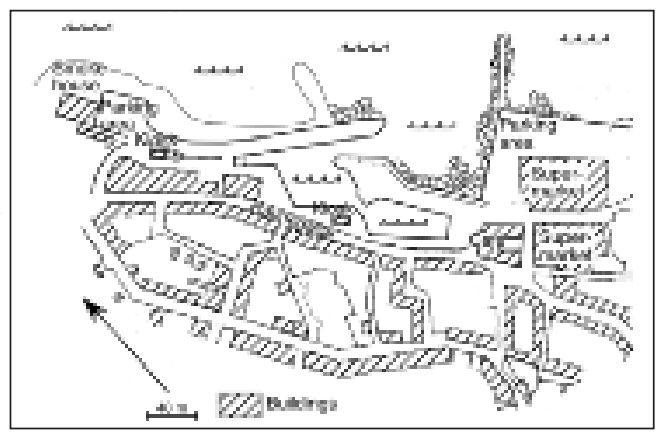

Fig. 1. Kort af miljøet omkring Allinge Havn. Tegner: Ingrid Jensen på opdrag af Jorgen Ole Berenholdt, forst trykt i Barenholdt et al. 2004: 36.

granitbrydning uden for byen blev sprængt ud af granitundergrunden i flere sekvenser fra 1862 til 1919. Turismen daterer sig tilbage til denne samme historie, formidlet gennem den tyske forbindelse og har også sat sig materielle spor. Det markante nu lukkede Høiers Hotel i havnens sydøst ende rummer nu foruden boliger havneområdets centrale cafe (se udsigt herfra på foto 1). Til sammen skaber disse anlæg en fornemmelse af havnen som et samlet og nogenlunde afgrænset rum, hvor det i vid udstrækning er muligt at følge aktiviteter på tværs med syns-, høre- og lugtesansen. Ved at bevæge sig rundt og indlade sig på forskellige former for forbrug, aktiveres også føle- og smagssansen, hvis ikke allerede stimuleret af oplevelsen af vind, vejr og bølgesprøjt. Havnen fungerer på sin vis som et torv, hvor det er muligt at høre f.eks. havnefogedens ordrer til de bugserende amatørsejlere eller musikopførelser overalt, hvortil kommer bl.a. bølgeslaget fra Østersøen og passerende biler, cykler og busser.

Den anden dimension, kropsligt sted, fremgår allerede af betydningen af den menneskelige, mobile, performance i det fysiske miljø. Der 
er således forskellige typer af måde at slentre på. Blandt dem er der f.eks. midaldrende ægtepar ('empty nesters') som 'tuller rundt' (interview) for at nyde atmosfæren, mens børnefamiliers oftest heftigere besøg i et sådant miljø er mest udbredte på tidspunkter, hvor vejret er mindre egnet til badning og solbadning. Undervejs, mens de 'krydser' igennem havneområdet og 'ser sig omkring' tales der om forskellige mulige skridt i oplevelsespraksis, hvilken dag som f.eks. vil være bedst til at tage til Christiansø, om det skal være herfra eller fra et andet sted, og ikke mindst hvor man skal indtage frokost og siden hen aftensmad. Med forskellig hast og forskellige mål og ruter, mere eller mindre driver folk omkring. Der botaniseres i forretninger, kiosker og livet nede i lystbådene observeres. Havnegade ligger flere meter over vandspejlet og dermed en oplagt, langstrakt og ikke mindst 'tilfældig' observationspost. For alle disse oplevelser er den kropslige tilstedeværelse og involvering i omgivelserne et sine qua non. Vi er her ved et centralt punkt i den fænomenologiske stedsopfattelse, som i turismeforskningen har manifesteret sig igennem studier af turisters performance, som mere end kulturelt forud koreograferet. Kerneformuleringer i denne forståelse er: 'We live place not only culturally, but bodily' (Crouch et al. 2001: 259) og '... bodies are not only written upon but also write their own meanings and feelings upon space in a process of continual remaking' (Edensor 2000b: 100). Kropslig praksis er afgørende, og det er for at understrege betydningen af den konkrete 'udspilning' af praksis, at performance begrebet indføres som en specificering. Men feltstudiet begrebsliggør samtidig, at den kropslige performance ikke blot er i samspil med de fysiske omgivelser men også involverer det sociale i performance.
Sted som socialitet er således den tredje og ganske centrale dimension af stedsanalysen. Socialitet foregår ikke kun på enkeltsteder, hver for sig, men foregår også i forbindelser med andre steder, og den udleves igennem mobile praksisformer, også 'inden for samme sted'. Det er i høj grad gennem performance af sociale relationer med andre (jf. Goffman), at oplevelser og identitet bliver til. Men der er mange former for socialt sted på spil på Allinge Havn: Folk er sammen med deres nære og kære, ikke blot under slentreturen, på cafeen og røgeriet - men også ombord på lystbåde og i passerende biler og busser. Samtidig 'overvåger' de det komplekse sceneri som udspilles: Flere turister lægger vægt på den afslappende atmosfære, som også knytter til sig til bestemte butikker eller røgerier, som må genbesøges ved hvert besøg. Allinge som sted tilknyttes kvaliteter som hygge og god stemning, som samtidig er et generelt vigtigt attraktionsmoment ved de bornholmske bymiljøer.

I oversigtlig form kan sted som socialitet opdeles i fire forskellige undertyper: Der kan være tale om den allerede beskrevne generelle atmosfære, som bliver til igennem tilstedeværelse og performance af mange andre gæster. Dertil kan socialiteten udspille stedet gennem bestemte begivenheder, som f.eks. en jazz festival, eller aktiviteter, som f.eks. at spise på røgeriet. Naturligvis bidrager disse begivenheder og aktiviteter til den generelle atmosfære, ligesom de næres af den. Det gælder også for de mere specifikke og fokuserede møder ('encounters') mellem folk, det være sig mellem turister, mellem turister og lokale osv. og i forskellige former, hvor det kan hænde at forskellige former for mere diskret hilsen performes. Endelig er der naturligvis socialiteten indenfor den gruppe eller familie, som rejser sammen. Stedets socialitet er altså ikke en given ramme, 
14 men noget som produceres gennem social interaktion (Goffman) men også gennem en mere diskret opmærksomhed om andres tilstedeværelse, hvor den enkeltes performance kun relaterer sig indirekte til andres performance. Tim Ingold udtrykker det således: 'The temporality of the taskscape is social, then, not because society provides an external frame against which particular tasks find independent measure, but because people, in the performance of their tasks, also attend to one another ... we continually feel each other's presence in the social environment ... the gestures of the performers may be said to resonate with each other ...' (Ingold 2000: 196).

Resonans udøves ikke kun på det enkelte sted, men netop i høj grad gennem rejsen gennem flere steder - og ved gruppens samtidige tilstedeværelse på flere steder, ofte forbundet og koordineret gennem mobiltelefonisk interaktion, startende med 'hvor er du?'. Sted som socialitet er imidlertid kun mulig at generalisere $\mathrm{i}$ et begrænset omfang. Hvad der f.eks. blev oplevet som et hyggeligt og afslappet sted for 'empty nesters', blev for det unge par kun 'ganske hyggeligt' i betydningen, at der findes andre og mere spændende steder at tage hen. Der er altså alligevel øjensynlig en vis kulturel kodning af den resonans, som Ingold omtaler (ligesom enhver form for musik jo også har sine kulturelle kodninger).

Det kropslige sted og sted som socialitet refererer endvidere meget ofte til den fjerde dimension: Sted som erindring. Her tænkes ikke så meget på erindringen om besøget på stedet bagefter, men derimod på den erindring om det samme sted tidligere og andre steder, som altid er involveret $\mathrm{i}$ og mobiliseres gennem stedsoplevelse. De erindringer som er involveret er samtidig altid allerede sociale, fordi mennesker husker sammen og ved fælles ind- sats, herunder gennem højtider og institutionalisering, ligesom også glemsel performes socialt (Urry 1995: 27). Et vigtigt instrument som ofte anvendes til produktion af fremtidig erindring er fotografering (se næste afsnit om Hammershus), men Allinge Havn er ikke noget udbredt fotosted. Den form for erindring som især udtrykkes, er knyttet til tidligere besøg. Mange familier besøger de samme steder igen med kortere eller længere tid imellem, og ved disse genbesøg formidles og bearbejdes en fælles historie, ligesom der foregår en inkluderende socialisering af evt. nytilkomne børn, kærester m.fl. Familier fortalte om, hvordan de altid måtte til Allinge Havn for at slentre og shoppe i de samme butikker, kiosker og omgivelser, som de plejede. Besøget er i sig selv monitorering af stedet, for at forsikre sig om dets fortsatte eksistens (som jo samtidig kun er i og med opleverens erindrende praksis) og nøje observere evt. forandringer.

Mange centrale livsoplevelser knytter sig til disse ellers 'uskyldige' aktiviteter, f.eks. 'kan du huske det var den gang du var meget mindre / du var syg / du netop havde mistet din mor / vi netop havde fået vores baby'. Stedsbesøget indebærer således allehånde erindringer, som har med livsforløb og vores færden igennem stort og småt at gøre. David Crouch udtrykker det således: 'We think over where we have come from and how far we have come and where else we desire to go. We negotiate an awkward slope. We make little judgments, reflexively we talk things over, mixing and remixing all of these impulses and desires. There are particular things in this place, another encounter, recent memories of similar places and what we did there' (Crouch 2002: 211).

Sted som erindring knytter sig endelig også til den mere direkte brug af stedsimages. Det er godt nok karakteristisk at Allinge Havn om- 
gærdes af forholdsvis få direkte repræsenterede og præsenterede stedsfremstillinger; noget som i nogen grad står i kontrast til den rolle stedsmyter spiller i forskningen (f.eks. Shields 1991). Det er måske netop derfor, Allinge Havn er en god case for en fænomenologisk og 'Non-Representational Theory' stedsanalyse. Fra et kulturarvsorienteret eller musealt synspunkt kan dette måske synes forunderligt, al den stund at Allinge Havn jo i sig (som her kun antydet) rummer megen kulturarv knyttet til oversvømmelser og havnebygning og arkitektur, granitindustri, turisme, fiskeri, sejlads og handel. Men den er hengemt på stedet, til f.eks. de fotokopierede gamle fotos af havnen og skibe, som hænger på væggen i cafeen og i havnefogedens lille kontor.

Oplevelsen af Allinge Havn konstitueres i det fortættede fysiske miljø gennem først og fremmest den intrikate kombination af kropsligt sted, sted som socialitet og sted som erindring. Det er denne kombination som 'sammenkaster' (Massey 2005) folk på stedet igennem forbindelser, som indeholder forskelligartede intensitet og tids-rumlig organisering. Tid og rum artikuleres på særlige måder, når mennesker oplever et sted med distinkte kvaliteter og følelser. De gør det med kroppene heftigt involveret, de gør det sammen og de gør det i erindring om andre stedsoplevelser her og der. $\mathrm{Vi}$ bevæger os nu videre med en kortere diskussion af turistfotografering på det nærliggende Hammershus.

\section{FAMILIEBLIKKET PÅ HAMMERSHUS}

Hammershus er et centralt kulturavssted i dansk og bornholmsk histoire. Det er et nærmest obligatorisk turiststed for besøgende på Bornholm; det indtager således en ikonisk central rolle i mange kulturelle og markedsfø- ringsmæssige repræsentationer af Bornholm.

Ofte fortalte dramaer udspilledes her i middelalder og renæssance, og genopbygningen af ruinen i 1800-tallet var ledsaget af frembringelse af mange kendte malerier. Hammershus er altså en slags 'must' - at besøge. Dets storhed i historie og landskab understreges af, at der altid er fri adgang. Og der er da også altid mange besøgende $\mathrm{i}$ turistsæsonen. Sjovt nok er der nok mange gæster, som bruger mange flere fotos på Hammershus - men alligevel mindre tid end i Allinge, som mange passerer og besøger på vejen. Og den kulturhistoriske formidling er ganske begrænset, den består i en mindre udstilling med entre i tilknytning til det noget mere besøgte cafeteria og kiosk nær P-pladsen samt enkelte skilte inde på borgen. Hammershus er for mange besøgende mere end et stykke formidlet kulturhistorie et monument placeret i et (særligt efter danske forhold) ganske ekstraordinært landskab med stejle klippesider ned mod havet, udsigter osv. Stedets fysiske aspekter involverer en nødvendig gåtur opad toppede brosten eller ujævne trapper.

Studiet af turismeperformance på Hammerhus blev foretaget $\mathrm{i}$ Jonas Larsens ph.d. afhandling (Larsen 2003), som også er formidlet $\mathrm{i}$ flere andre arbejder (Haldrup og Larsen 2003, Bærenholdt et al. 2004, Larsen 2005 og 2006a). Ph.d. arbejdet blev vejledt af nærværende forfatter, som fra det nærliggende familiesommerhus selv også en flittig familiegæst på Hammershus. Hvad der startede med at skulle være et studie af fotografier, blev til en nyskabende analyse af den performance, det er at tage turistfotos. Af observationer af fotografering, interviews med fotograferende turister og indsamlede fotografier fra turisterne fremgik det, at turisters fotografering er betydeligt mere end andet end blot at finde og samle 
16 fotografierne, svarende til de som allerede er kendt fra brochurer, TV etc. Studiet kom dermed til at præcisere og nuancere en række aspekter af hvordan 'turistblikket' (Urry 2002) konstitueres. Turistfotografering bryder med den ofte fremførte, alt for deterministiske, opfattelse, at den kun handler om den 'hermeneutiske cirkel' at indsamle allerede kendte fotos for at dokumentere, at man har været der. Det viste sig, at en række kropslige, sociale og erindringsmæssige aspekter er afgørende i etableringen af det som blev kaldt 'familieblikket' (Haldrup og Larsen 2003, Bærenholdt et al. 2004).

Først er det vigtigt at den fysiske indretning af borgruinen med dens stier, bænke, skilte og udsigtsposter bidrager til at iscenesætte turistperformance. Men dernæst og nok så vigtigt involverer fotografering, som vitterlig er en central turistpraksis på Hammershus, en række centrale kropsligt performative elementer. Folk gør sig umage med at komponere fotos, og må derfor stille sig alle mulige steder i forskellige, ofte ret umulige, kropslige stillinger. Endelig er der langt fra kun tale om 'romantiske' fotografier af Hammershus; det er i mindst lige så høj grad tale om familiefotos, men herunder gerne sådanne, hvor Hammershus er den tydeligt identificerbare kulisse. Fotograferingen involverer opstillingen af familien som en dokumentation af at 'vi var der sammen' og det sker med en ganske bevidst hensigt om i fremtiden at erindre dette sammen. Historiefortællingen som udspilles er i mindre grad møntet på bestemte begivenheder end den fokuserer på den fantaserede 'barnlige' leg med krig, som borgruinen på bedste vis muliggør ('affords'). Hammershus som sted er som regel på forhånd mere eller mindre kendt, men stedet opleves i det konkrete møde, hvor den kropslige bevægelse i socialt samvær med an- dre i familien, parret eller gruppen konstituerer stedsoplevelsen. Andre tilstedeværende, fremmede, turister er snarere end atmosfæreskabere 'i vejen' for oplevelsen, herunder for fotograferingen af de udvalgte, som er/skal med (se foto 2).

Hammershus er kulisse for sted som socialitet og erindring. Ikke blot 'genspilning' af tidligere erindring, men som led $\mathrm{i}$ en intenderet produktion af fremtidig erindring gennem fotos. Der forbindes således ikke kun til sted over tid i fortiden men også i fremtiden. Som turisterne udtrykte det, tager de fotos af stedet med familien i centrum. Man skal kunne se, at de er på ferie sammen, men Hammershus skal også kunne identificeres i baggrunden. Der et element af pilgrimsrejse over besøget: stedet er et kendt ikon og mange genbesøger monumentet, som om det var et Taj Majhal i ministørrelse (se Edensor 1998).

Erindringen om socialitet på stedet kan siges at være et ledemotiv - ikke bare for fotografering, men også for den turismeperformance, som den er indbegrebet af. Turistperformance bliver dermed helt fra starten et socialt forbindelsesprojekt med andre mennesker, rettet mod fremtidens erindring. 'The photograph, as a snapshot, is similar to the poetic image in that it represents place as time remembered, such that it has a after-life and a mobility outside of the immanence of its becoming. Viewing snapshots from one's intimate life, of loved ones in particular, either when young or after they are dead, is an example of the process of the sensous recovery of the intimacy of the Other through the remembering of places (heterogeneous material assemblages) where one has been' (Hetherington 1997: 196). Det er tydeligt, at skønt vi her har at gøre med interpersonelle og nærmest eksistentialistisk betydningsfulde relationer, kan fænomenolo- 


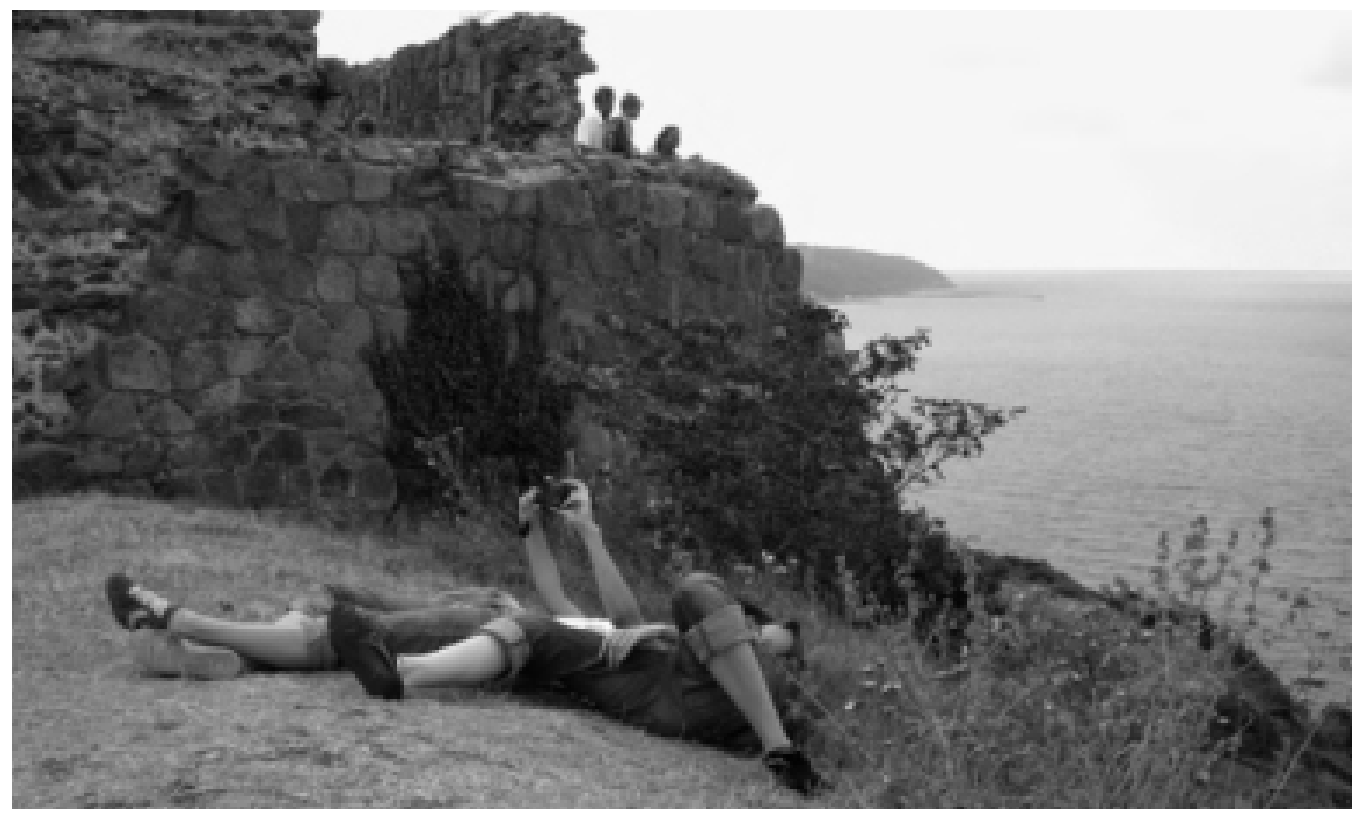

Fotografering som erindring om samvar, Hammershus. Foto: Jorgen Ole Barenholdt. Bemark at dette foto fra 2007 angiveligt demonstrerer nye aspekter - herunder billedforbrug på stedet - udviklet med udbredelse af digitalfotografering, som ikke var manifeste under Jonas Larsens feltarbejde i 2001, se i øvrigt Larsen $2006 b$.

gien inspirere, men på den anden side ikke helt rumme den fulde fortolkning. Det springende punkt i Hetheringtons 'kulturmaterialistiske' tilgang bliver at den inkluderer fotografier og steder som materielle 'sammenbygninger', der også har et 'efter-liv' ud over det umiddelbare tidsrum. Ligesom i fænomenologien er oplevelserne altså knyttet til mere end repræsentationer og deres hermeneutiske cirkler, men modsat f.eks. Ingolds fænomenologi, alle andre kvaliteter ufortalt, kan den rumme den teknologisk medierede samtilstedeværelse og sammenbygning af steder på tværs af tid og rum. Det er dette perspektiv, som forfølges nærmere i det følgende eksempel, hvor genoplivningen af den historisk materielle kulturarv tager mere plads.

\section{KULTURARVENS FANTASTISKE REALISME PÅ} VIKINGESKIBSMUSEET

Vi bevæger os fra den mere eller mindre eksplicitte kulturarv 'ude i det fri' og ind på et museum, som imidlertid i de senere har bevæget sig mere og mere 'ud i det fri', i flere betydninger: For det første har Vikingeskibsmuseet i Roskilde ved siden af sin modernistiske udstilling af de auratiske vrag i Vikingeskibshallen udviklet sin museumsø som arena for udendørs bygning af skibskopier, turistsejlads, åbent konserveringsværksted og andre turistinvolverende aktiviteter (se figur 2). For det andet er museets eksperimentelle maritime arkæologi mobiliseret i mere vidtgående betydning, da kopiskibene bringes på langvejs sej- 
18 lads, senest og mest spektakulært med Skuldelev 2 kopien Havhingsten fra Glendalough, som i sommeren 2007 blev sejlet til Dublin for at overvintre og blive udstillet på Irlands Nationalmuseum. En begivenhed, som i tråd med optræden i National Geographic og BBC udsendelser er blevet kraftigt mediedækket og italesat, i en grad som involverer både politiske tilsagn om støtte og den lokale befolknings medleven og indlevelse. Endelig kan man sige, at Vikingeskibsmuseet med denne mobilisering af kulturarven har bragt sig ud i en friere kulturarvsformidling, end den som traditionelt har kendetegnet museer. Der er måske tale om en relativ frigørelse fra et traditionelt museumsparadigmes orientering mod det betragtende øje og mod autencitet i traditionel forstand, kendt fra sin adskillelse af publikum fra de auratiske objekter (Hetherington 1999, 2002). Men endnu er Vikingeskibsmuseet også et konkret sted, der i kraft af sine bygninger, vrag, tableauer, forestillinger og forskellige typer af kopier og aktiviteter bidrager til at stabilisere virksomheden og oplevelsesproduktionen (om disse mere regionale-økonomiske-organisatoriske-medarbejderorienterede aspekter se Bærenholdt og Haldrup 2006, samt Bærenholdt 2007).

Nærværende studie bygger på forfatterens feltarbejde på nogle varme sommerdage i 2003, som bestod af observation, interview med medarbejdere (se også Bærenholdt 2007) og med besøgende turister med henblik på en analyse af kulturturistperformance (Bærenholdt og Haldrup 2004, hvori studiet er udfoldet). Studiet indgår i forlængelse af per-

Fig. 2. Oversigt over Vikingeskibsmuseet i Roskilde. Tegning: Vikingeskibsmuseet, modificeret af Ingrid Jensen på opdrag af Jørgen Ole Barenholdt, først trykt i Barenholdt og Haldrup 2004: 80.

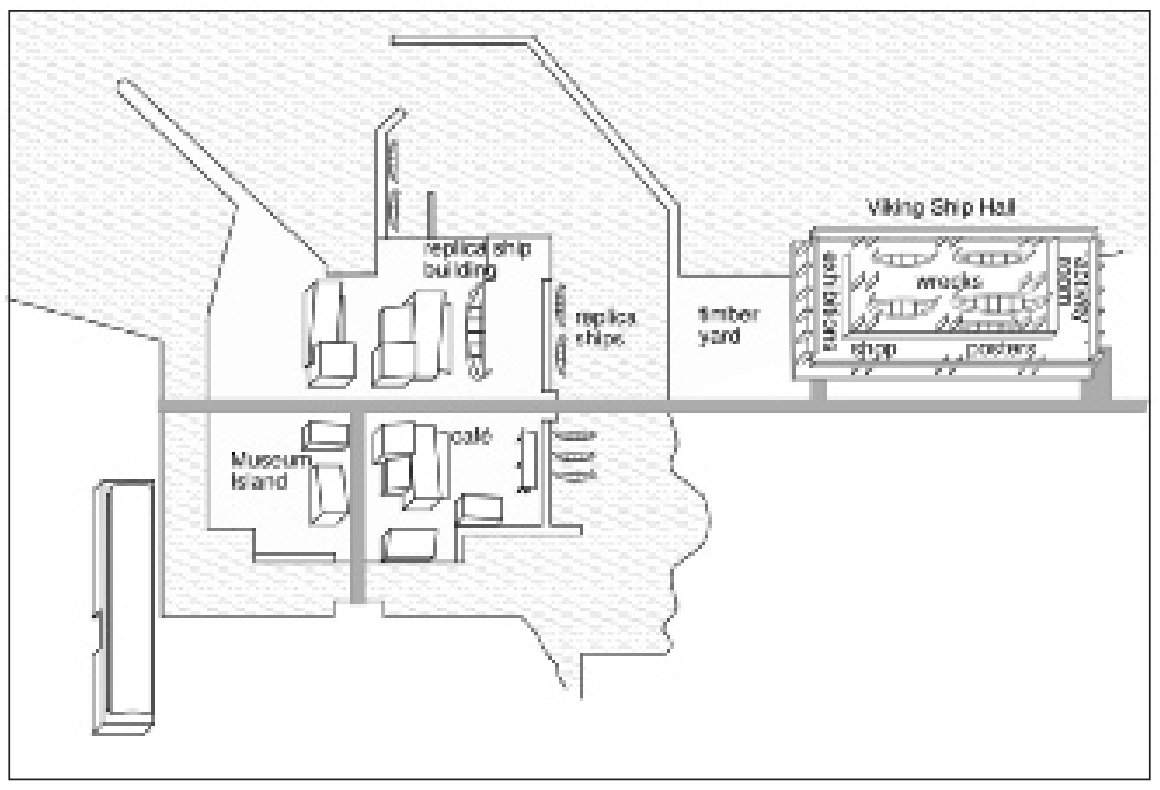




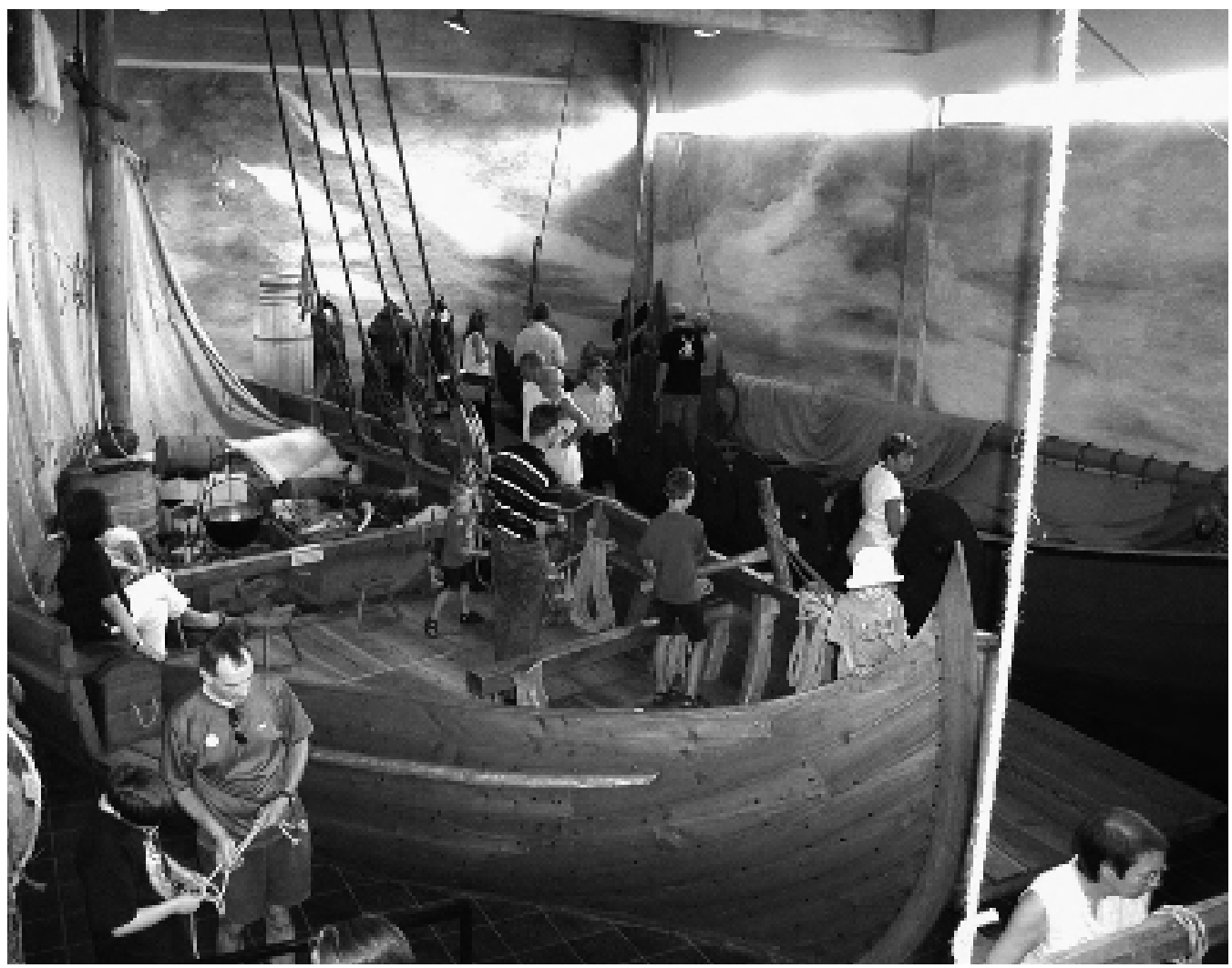

Turistaktiviteter i Vikingeskibshallens 'Øst-rum'. Foto: Jørgen Ole Barenholdt.

formancetilgangen til turisme i den kritiske geografi-inspirerede turismeforskning (se bl.a. Crang 1994, 1996). Kulturarvssteder studeres her som aktive 'sites' for fortolkning, som er nært forbundet med kropslige og forestillede performances, befordret ('afforded') af stedets materielle, social og kulturelle organisering. Vikingeskibsmuseet er her et interessant sted, siden det kombinerer meget forskellige typer af kulturarv. Ikke blot kontrasten med den stilistisk enkle opstilling af vragresterne i hallen og det, som nogle turister kalder de 'rigtige skibe', som fremstilles og sejler fra museumsø- en. I det bagerste 'Øst-rum' gemmer sig nemlig et aktivitetsrum, hvor mange turister efter den andagtsfulde passage af de auratiske vrag udfolder sig med påklædning, våbenkopier og runeskrift omkring to delvise vikingeskibskopier og med støtte af aktivt intervenerende studentermedhjælpere (se foto 3, se også analyse af besøgende guidede turister $\mathrm{i}$ Larsen 2003).

Vikingeskibsmuseet er, mere end de to andre studerede steder, en international turistattraktion; en af de få f.eks. amerikanske turister vil overveje at rejse efter i Skandinavien. Jeg har 
20 valgt især at fremhæve interessante aspekter fra interviews med besøgende amerikanske turister, fordi de demonstrerer betydningen af kultursteder over store afstand. Flere af de interviewede gav udtryk for, at deres rejse var et led i en søgning efter kulturarven fra deres egne skandinaviske forfædre. Et midaldrende ægtepar fra Hawaii med frisisk, skandinaviske forfædre gav klart til kende af de søgte efter sporene af deres forfædre, og var dybt fascinerede af den igangværende bygning af kopien af Skuldelev 2 på museumsøen. De forbandt ganske let deres eget og familiens liv på Hawaii med sporene efter forfædrene. De kom tilbage for at fotografere en tidlig sommermorgen

'because we are trying to explain to our grandchildren - their heritage, and this helps... And I'm so interested and amazed that long ago people had developed crafts; they were not literate, they had to make it originally.'

\section{og:}

'For us it is very hard to understand living on the ocean, living on ship for and extended time, because we have seen the ocean where we live; sometimes it is very calm, but at other times, like during hurricanes, it is very wild and ... they were very strong people, very creative and very clever at figuring out how to survive.'

Der producers her en forbundet fortælling om vikingernes fantastiske verden, hvor kreative og kloge de var, og så turisternes egen verden som efterkommere i mødet med havets udfordringer. De tilføjer morsomme historier om den mandliges parts fiskerfamilie i Seattle. Her forbindes bagud i tid til forfædre og deres forskelligartede præstationer og men- talitet forskellige steder, og forud til den planlagte, forestillede, fortælling og formidling af kulturarv til deres børnebørn hjemme på Hawaii. Fortolkningsmulighedernes righoldighed bliver her tydelige, og det er tydeligt at mere end de auratiske skibsvrag i 'den hellige Vikingeskibshal' er det det konkrete møde med kopiskibenes håndværk og sejlads, som befordrer de langtrækkende fantastiske forbindelser. Identifikationen gennem genealogien spiller her en voldsom rolle, men det er i grunden tilfældet ved megen kulturarvsproduktion. Det er næsten alle forbundet med produktionen af et særligt 'vi'. Dette illustreres tydeligt gennem denne overvejelse blandt, nogle ikke mindre begejstrede, amerikanske turister. En af to yngre søstre med baggrund i Taiwan fortalte:

'Oh, actually, I watched a TV programme on the History Channel talking about that, and they were trying to figure out who actually discovered America first - Columbus or someone else - and they did mention Vikings, but at some time they mentioned the Chinese sailors, I don't know how many years ago, and the whole programme struck me very much, because of the Chinese, not because of the Vikings ... we grew up in Taiwan ... so I hoped the Chinese discovered America.'

Det værdsatte besøg på Vikingeskibsmuseet, som involverer de forskellige elementer, giver anledning til vidtrækkende refleksioner over kulturarvens betydning. De giver stof til eftertanke for analysen af stedsoplevelse, eftersom en sær blanding af materiel-kropslig omgang med genstande og fantastiske fortællinger finder sted sammen.

Steder opleves i forbindelser, og det understreges i dette eksempel i særlig grad hvordan tiden kan foldes sammen og ellers tids-rumligt 
fjerne steder kan genoplives (se også Jóhannesson 2007 for eksempler på islandsk vikinge- og sagaturisme hvor det kombinerede fravær og nærvær af sagnfigurer levendegøres). Den særlige genre som performes i denne type kulturturisme, kan med inspiration fra bl.a. Tolkiens begreb om 'second-world' (1997) og Benjamins (1998) forståelse af spor ses som udtryk for en 'fantastisk realisme' (Bærenholdt og Haldrup 2004). Den er fantastisk fordi den indebærer en tydelig mobilisering af fantasi som forbinder ellers tids-rumligt fjerne performances og begivenheder. Men den er samtidig realistisk fordi den bliver til gennem den konkrete omgang med objekter, og der er således ikke i egentlig forstand tale om 'fri fantasi'; derimod om forestillingen af en verden og af forbindelser der er så reelle og rigtige, at de er til at tro på. Det er ikke objekterne i sig selv som mobiliserer (affords) fantasien, men det er snarere de spor og fjerne forbindelser som de giver anledning til, som gør det muligt at tilegne sig kulturarven gennem stedsoplevelsen. Walter Benjamin er nok den som har formuleret dette mest elegant i sit begreb om spor ('trace'), i kontrast til aura: 'The trace is the manifestation of a closeness however dist-anced it may be. The aura is the manifestation of a distance however close it may be. In the trace we enter into the possession of the thing, in the aura the thing overpowers us' (citeret i Markus 2001). Det gælder om at få fremstillet et univers, der er så realistisk rigtigt (Tolkien 1997), at fantasien kan trække sporet og skabe forbindelser, endda over store afstand i tids-rum. Det er altså snarere fantasien som skaber realismen end omvendt. 'Affordance' er vigtigt men duer ikke uden performance. Oplevelser af steder og deres forbindelser med bl.a. kulturarv kræver altså turistens aktive og fantasifulde indsats.
KONKLUSION: STEDER DER FLYTTER

En rejse gennem tre turiststeder, som i forskelligt omfang også er bosteder, kulturarvsteder og stedsprojekter, er tilendebragt. Erfaringerne undervejs peger ikke nødvendigvis det samme sted hen. Der er forskel på den kropslig, sociale og personligt erindringsorienterede turismeperformance på Allinge Havn, over den forbavsende sociale bevidste erindringsproduktion gennem fotografering på Hammershus, til internationale turisters mobilisering af forbindelsesrig, fantastisk realistisk, kulturarv på Vikingeskibsmuseet. Men på trods af disse forskelle, henviser især de to sidste steder på denne rejse til, at fænomenologiens opmærksomhed om personers kropsligt, sociale involvering i omgivelserne og hinanden må udfordres. Det er ikke fordi fænomenologien ikke, foruden kropslig og følelsesmæssig, også kan håndtere erindringsmæssig involvering. Men det er særligt, når vi kommer til de fortællinger og forestillinger, som er forbundet med kulturarven, som tilmed oftest er ret så politisk gestaltet (noget som ligger uden for denne artikels problematik), at det rent fænomenologiske perspektiv må overskrides til fordel for tilgange, som ser performance af oplevelser i forbindelse med fantasiproduktion i relation til samfundsmæssigt og kulturelt overleverede fortællinger og spor. Det er bemærkelsesværdigt at dette perspektivskift sker samtidigt med at steder gøres mobile, som foreslået af Kevin Hetherington (1997). Der var godt nok mænd, som på Allinge Havn drømte sig ud på rejser på Østersøen, og turister som på Hammerhus fantaserede over middelalderborgen som krigsscene mod angribende skibe; men det var disse steder mere det umiddelbare velvære som styrer sommerferieturismen. Det var især i Vikingemuseets mere 
22 direkte iscenesatte, museale, kulturarvsformidling, at fantasien kunne forbindes med genoplivning af vikingeskibenes sejlads, en forførende bevægelse af sindet til et andet sted, heterotopia, i tid og rum. Lad det her være usagt, at disse forbindelser ikke er uskyldige endsige upolitiske (se Buciek et al. 2006a). Der er f.eks. ikke mange besøgende indvandrere at se på Vikingeskibsmuseet og da Muhammedkrisen indebar demonstrationer mod Danmark i Damaskus var det bl.a. over parolen 'Dirty Vikings: How dare you?'. Der kan altså være meget på spil når den auratiske fjernhed overvindes af det konkrete spors nærhed.

Studierne fra Allinge Havn og Hammershus demonstrerer anvendeligheden af Goffmans mikrosociologiske tilgang til interpersonelle relationer. Men der er begge steder flere facetter på spil, som kræver en forståelse af turisters kropslige involvering i de materielle omgivelser, og hvordan denne involvering særligt i familiefotograferingen rækker ud i fremtiden. Det er også klart, at den fantastiske realisme, som er studeret blandt amerikanske turister på Vikingeskibsmuseet, kan anskues som performativitet i Butlers forstand. Men studiet foreslår en mere vidtgående fortolkning, hvor performance knyttes til et forbindelsesarbejde, der på tværs af tid og rum skaber en fantastisk anden forestillet, men ikke mindre virkelig, verden.

Den konkrete involvering med steder, som fænomenologien tematiserer, er imidlertid samtidig en nødvendig basis for at forstå, hvordan steder opleves materielt, kropsligt, socialt og erindringsmæssigt. Uden dette perspektiv er det svært at forstå, hvordan mennesker kommer til at forbinde steder på deres turistrejser og livsrejse. Det er også fænomenologien, som lægger grunden til forståelsen af mobilitetens betydning for stedsoplevelsen. Men det er i den ikke mindre væsentlige fantastiske oplivning af spor og forbindelser, udover den umiddelbare fænomenologi, at de livgivende - men heller ikke uskyldige - former for engagement og entusiasme bliver til.

\section{NOTER}

1. Artiklen er en videreudvikling af en forelæsning til ph.d. seminaret 'at opleve (på) stedet', SDU Campus Esbjerg, 4-5. oktober 2007. Jeg takker for reaktioner ved denne lejlighed - og for at kunne trække på tidligere fællesarbejder med Michael Haldrup, Jonas Larsen og John Urry, skønt denne artikel er helt mit ansvar. Mange tak for konstruktive kommentarer og forslag fra den anonyme peer reviewer.

\section{LITTERATUR}

Benjamin, Walter: Kulturkritiske essays. Samlerens bogklub: København 1998.

Buciek, Keld; Jørgen Ole Bærenholdt og Kristine Juul: Whose heritage? Immigration and place narratives in Denmark. Geografiska Annaler: Series B, Human Geography, Vol. 88, 2006a: 18597.

Buciek, Keld; Jørgen Ole Bærenholdt, Michael Haldrup og John Pløger (red.): Rumlig Praksis: Festskrift til Kirsten Simonsen, Roskilde Universitetsforlag: Frederiksberg 2006b.

Butler, Judith P.: Bodies that Matter: On the Discursive Limits of Sex. Routledge: London 1993.

Bærenholdt, Jørgen Ole. Transaktioner: Medarbejdere og oplevelser i kulturøkonomien. I Bærenholdt og Sundbo (red.) Oplevelsesøkonomi: Produktion, Forbrug, Kultur. Samfundslitteratur: Frederiksberg 2007. 
Bærenholdt, Jørgen Ole og Brynhild Granås: Places and Mobilities beyond the Periphery. I Bærenholdt og Granås (red.) Mobility and Place: Enacting Northern European Peripheries. Ashgate: Aldershot 2008.

Bærenholdt, Jørgen Ole og Michael Haldrup: On the track of the Vikings. I Sheller og Urry (red.) Tourism Mobilities: Places to play, places in play. Routledge: London 2004.

Bærenholdt, Jørgen Ole og Michael Haldrup: Mobile Networks and Place Making in Cultural Tourism. European Urban and Regional Studies. Vol. 13, 2006: 209-24.

Bærenholdt, Jørgen Ole; Michael Haldrup og Jonas Larsen: Performing Cultural Attractions. I Sundbo og Darmer (red.): Production of Experiences, Edward Elgar: Cheltenham, I trykken (med forbehold for endelige titler).

Bærenholdt, Jørgen Ole; Michael Haldrup; Jonas Larsen og John Urry: Performing Tourist Places. Ashgate: Aldershot 2004 (genoptrykt 2007).

Coleman, Simon og Mike Crang (red.) Tourism between Place and Performance. Oxford: Berghahn Books 2002.

Crang, Mike: On the Heritage Trail: Maps of and journeys to Olde Englande. Environment and Planning D: Society and Space. Vol. 12, 1994: 341-55.

Crang, Mike: Magic Kingdom or a Quixotic Quest for Authenticity. Annals of Tourism Research. Vol. 23, 1996: 415-31.

Crouch, David: Surrounded by Place: Embodied Encounters. I Coleman og Crang (red.) Tourism between Place and Performance. Oxford: Berghahn Books 2002.

Crouch, David, Lars Aronsson og Lage Wahlström: Tourist encounters. Tourist Studies, Vol. 1, 2001: 253-70.

Edensor, Tim: Tourists at the Taj: Performance and Meaning at a Symbolic Site. London: Routledge 1998.
Edensor, Tim: Staging Tourism: Tourists as Performers. Annals of Tourism Research, Vol. 27, 2000a: 322-344.

Edensor, Tim: Walking in the British Countryside: Reflexivity, Embodied Practices and Ways to Escape. Body and Society. Vol. 6, 2000b: 81-106.

Goffman, Erving: The Presentation of Self in Everyday-Life. Anchor Books: New York 1959.

Haldrup, Michael: Materialitet og praksis i skabelsen af oplevelsesrum. I Buciek et al. (red.): Rumlig Praksis: Festskrift til Kirsten Simonsen, Roskilde Universitetsforlag: Frederiksberg 2006.

Haldrup, Michael og Jonas Larsen: The Family Gaze. Tourist Studies, Vol. 3, 2003: 23-45.

Hetherington, Kevin: In place of geometry: the materiality of place. I Hetherington og Munro (red.) Ideas of Difference. Blackwell: London 1997.

Hetherington, Kevin: From Blindness to Blindness: Museums, Heterogeneity and the Subject. I Law og Hassard (red.) Actor Network Theory and After. Blackwell: London 1999.

Hetherington, Kevin: The Unsightly: Touching the Parthenon Frieze. Theory, Culture and Society. Vol. 19, 2002: 187-206.

Ingold, Tim: The temporality of the landscape. I The Perception of the Environment. Routledge: London 2000.

Jóhannesson, Gunnar Thór: Emergent Tourism: An Actor-Network Approach to Tourism. Ph.d. afhandling i geografi, Institut for Miljø, Samfund og Rumlig Forandring, Roskilde Universitetscenter: Roskilde 2007.

Larsen, Jonas: Performing Tourist Photography, Ph.d. afhandling i geografi, Institut for Geografi og Internationale Udviklingsstudier og Dansk Center for Turismeforskning, Roskilde Universitetscenter: Roskilde 2003.

Larsen, Jonas: Families seen photographing: Performativity of tourist photography. Space and Culture, Vol. 8, 2005: 416-34. 
24 Larsen, Jonas: Picturing Bornholm: Producing and Consuming a Tourist Place through Picturing Practices. Scandinavian Journal of Hospitality and Tourism. Vol. 6, 2006a: 75-94.

Larsen, Jonas: Fotografi i en digital tidsalder. Nordisk Sambällsgeografisk Tidsskrift, nr. 41/42, 2006b: 35-57.

Löfgren, Orvar: On Holiday. Berkeley: University of California Press 1999.

Markus, Georgy: Walter Benjamin, or: The Commodity as Phantasmagoria. Theory, Culture and Society, Nr. 83, 2001: 3-42.

Massey, Doreen: Space, Place and Gender. Polity: Oxford 1994.

Massey, Doreen: The conceptualization of place. I Massey og Jess (red.): A Place in the World. The Open University and Oxford University Press: Oxford 1995.

Massey, Doreen: For Space. Sage: London 2005.

Mazzullo, Nuccio og Tim Ingold: Beeing Along: Place, Time and Movement among Sámi People. I Bærenholdt og Granås (red.) Mobility and Place: Enacting Northern European Peripheries. Ashgate: Aldershot, 2008.

Simonsen, Kirsten: Sted, køn og social praksis - om en 'kønnet' forståelse af stedsbegrebet. Nordisk Sambällsgeografisk Tidskrift. Nr. 21, 1995: 22-32.

Simonsen, Kirsten: Rum, sted, krop og køn. I Simonsen (red.) Praksis, rum og mobilitet: Socialgeografiske bidrag. Roskilde Universitetsforlag: Frederiksberg 2001.

Simonsen, Kirsten: Byens mange ansigter. Roskilde Universitetsforlag: Frederiksberg 2005.

Simonsen, Kirsten: Place as Encounters: Practice, Conjunction and Co-existence. I Bærenholdt og Granås (red.) Mobility and Place: Enacting Northern European Peripheries. Ashgate: Aldershot 2008.

Shields, Rob: Places on the Margin. Routledge: London 1991.

Thrift, Nigel: Performance and performativity: a geo- graphy of unknown lands. I Duncan, Johnson og Schein (red.). A Companion to Cultural Geography. Blackwell: Oxford 2004.

Tolkien, J.R.R. The Monsters and the Critics, and other Essays. HarperCollins: London 1997.

Urry, John: Consuming Places. Routledge: London 1995.

Urry, John: The Tourist Gaze, Sage: London 2002 (second edition).

* Jørgen Ole Barenholdt, ph.d. og dr. scient. soc., lektor i geografi Leder af forskningsgruppen 'Rum, Sted, Mobilitet og By' (MOSPUS) og tilknyttet Center for Oplevelsesforskning, Institut for Miljø, Samfund og Rumlig Forandring (ENSPAC)

Address: Bygning 02, Roskilde Universitetscenter (RUC, Postboks 260, DK-4000 Roskilde. job@ruc.dk 